\title{
Humanização e Saúde Mental: Reflexões Acerca das Práticas de Cuidado em Residências Terapêuticas, e para Além Deste Serviço
}

\author{
Cunha, Larissa Santana; Melo, Liliana da Escóssia \\ Universidade Federal de Sergipe - larissasc89@outlook.com
}

Introdução: a partir da experiência de estágio curricular com duração de 1 ano nos serviços referentes à atenção psicossocial de determinado município, o trabalho é desenvolvido no sentido de descrever, e promover uma reflexão sobre práticas de humanização no cuidado ao paciente no campo da Saúde Mental, mais especificadamente, no modelo de serviço conhecido por Residências Terapêuticas (RTs). Assim, o presente estudo, baseado em relato de experiências, inicialmente apresenta breve descrição do funcionamento da rede de atenção psicossocial que fundamenta os serviços prestados pelo município através dos modelos substitutivos (anti-manicomais): CAPS (Centro de Atenção Psicossocial) e RTs, além de outros aparelhos, como a Urgência e Emergência Psiquiátrica, e leitos em Hospitais Gerais. Posteriormente, parto ao apanhado teórico, e por último descrevo as atividades desenvolvidas, com ênfase nas práticas dos CAPS e das RTs, juntamente com suas análises e reflexões. Finalizo o estudo com um trecho referente ao exercício de pensamento sobre a Humanização nas RTs, dentro de tal modelo assistencial, frente aos egressos de hospitais psiquiátricos e demais moradores, evocando outras questões igualmente pertinentes dentre do eixo temático de cuidado ao paciente. a relevância do mesmo se apresenta ao passo que refletimos diretamente sobre as possíveis formas de se reconhecer humanização no vasto e complexo âmbito da saúde mental. Objetivos: o trabalho tem o intuito de apresentar descrição da experiência de estágio, onde foi possível acompanhar as atividades desenvolvidas no campo da saúde mental. com ênfase em captar os fazeres e as reverberações de práticas humanizadas neste âmbito da saúde, também se destina a fazer eclodir análises e implicações acerca de tais fazeres, e para além destes, promovendo levantamentos acerca das significações que se tem sobre humanização em saúde. Metodologia: Referindo-se a um relato de experiência, o trabalho tem como metodologia a observação participante, tendo sido desenvolvida a partir de idas semanais ao campo, e com o acompanhamento de supervisão técnica nos serviços, e supervisão acadêmica. o arcabouço teórico norteador para a inserção no campo se concentrou nos seguintes temas de estudo e discussão: Reforma Psiquiátrica, Política Nacional de Saúde Mental, Política Nacional de Humanização (PNH), Sistema Único de Saúde (SUS), Movimento Institucionalista, dentre outros. Resultados: Convergem para a reflexão de que são inúmeras e variadas as práticas humanizadas que foram possíveis de serem mais do que vistas, sentidas nos serviços de RTs, como exemplo de dispositivo de saúde mental. Conclusão: Atenta-se para o perfil de cuidadores que trabalham nas RTs, e as formas humanizadas que eles tratam e concebem a loucura, tendo ferramentas básicas de humanização enquanto valiosas artimanhas em momentos de crise e no cotidiano das casas.

Cunha, Larissa Santana; Melo, Liliana da Escóssia. Humanização e Saúde Mental: Reflexões Acerca das Práticas de Cuidado em Residências Terapêuticas, e para Além Deste Serviço. In: Anais do Congresso Internacional de Humanidades \& Humanização em Saúde [= Blucher Medical Proceedings, num.2, vol.1]. São Paulo: Editora Blucher, 2014. ISSN 2357-7282

DOI 10.5151/medpro-cihhs-10571 